\title{
Polymorphisms of the prion protein gene (PRNP) in Hanwoo (Bos taurus coreanae) and Holstein cattle
}

\author{
Byung-Hoon Jeong ${ }^{1}$, Hyun-Joo Sohn ${ }^{2}$, Jong-O Lee ${ }^{2}$, Nam-Ho Kim ${ }^{1}$, Jae-Il Kim ${ }^{3}$, \\ Se-Young Lee ${ }^{2}$, In-Soo $\mathrm{Cho}^{2}$, Yi-Seok $\mathrm{Joo}^{2}$, Richard I. Carp ${ }^{3}$ and Yong-Sun Kim ${ }^{1 *}$ \\ ${ }^{1}$ Ilsong Institute of Life Science, Hallym University, 1605-4 Gwanyang-dong, Dongan-gu, \\ Anyang, Kyounggi-do 431-060, South Korea \\ ${ }^{2}$ National Veterinary Research and Quarantine Service, Anyang, Kyounggi-do \\ 430-824, South Korea \\ ${ }^{3}$ New York State Institute for Basic Research in Developmental Disabilities, \\ Staten Island, NY 10314, USA
}

(Received 28 February 2005, accepted 19 July 2005)

\begin{abstract}
Polymorphisms in the prion protein gene $(P R N P)$ in humans and sheep correlate with susceptibility to transmissible spongiform encephalopathies (TSEs). Bovine spongiform encephalopathy (BSE) has been reported in British and Japanese cattle; it has occurred thus far in Holstein cattle. BSE in Hanwoo (Bos taurus coreanae) cattle has not been diagnosed up to now. To characterize the bovine PRNP polymorphisms in Korean cattle, we analyzed the open reading frame (ORF) of $P R N P$ in 120 Hanwoo (beef) cattle and 53 Holstein (dairy) cattle. Three polymorphisms were found, the third position of codon $78(\mathrm{G} \rightarrow \mathrm{A})$, the third position of codon $192(\mathrm{C} \rightarrow \mathrm{T})$, and the deletion of a single octa-repeat. An analysis of codon 78 revealed no difference in the genotype $(P=0.2026)$ or allele $(P=0.7180)$ frequencies between Hanwoo and Holstein animals. However, there were significant differences in the genotype $(\mathrm{P}<0.0001)$ and allele $(\mathrm{P}<0.0001)$ frequencies at PRNP codon 192 between Hanwoo and Holstein animals. The rate of Holstein animals with deletion of a single octa-repeat was $91.5 \%$ undeleted homozygotes, 8.5\% heterozygotes (with R3 deletion), and 0\% deleted homozygotes. However, none of the 120 Hanwoo animals had any octa-repeat deletions. The genotype $(P$ $<0.0001)$ and allele $(P<0.0001)$ frequencies of a single octa-repeat-deletion were also significantly different between Hanwoo and Holstein animals.
\end{abstract}

Key words: prion protein gene, polymorphism, bovine spongiform encephalopathy, Hanwoo, Holstein, cattle

Bovine spongiform encephalopathy (BSE) is a fatal infectious neurodegenerative disease which affects the nervous system of cattle (Wells et al., 1987). A typical characteristic of this disease is the accumulation of an abnormal, protease-resistant prion protein $\left(\mathrm{PrP}^{\mathrm{Sc}}\right)$ in the brain. The normal $\operatorname{PrP}, \operatorname{PrP}^{\mathrm{C}}$, is expressed in most tissues of the body and is readily digested by proteases. The gene encoding the prion protein in cattle is located on chromosome 13 (Ryan and Womack 1993). The prion protein gene $(P R N P)$ extends over $20 \mathrm{kbp}$, and the fulllength mRNA, produced from three exons, is $4.2 \mathrm{~kb}$, which includes the complete exon 3 sequence (Yoshimoto et al., 1992; Horiuchi et al., 1998).

Hanwoo (Han means Korean and woo means cattle) are known to have originated from crossbreeding between

Edited by Toshihiko Shiroishi

* Corresponding author. E-mail: yskim@ hallym.ac.kr
Bos indicus in India and Bos primigenius in Europe. They moved from China to Korea and have been in the Korean peninsula for at least 2000 years. Most dairy cattle bred in Korea are the Holstein breed. Holstein cattle have been reported to develop BSE in Japan and the United Kingdom (UK) (Hope et al., 1988; Kirkwood and Cunningham 1994; Kimura et al., 2002). However, BSE has never been diagnosed in surveys of Hanwoo in Korea (Koo et al., 2001).

In humans and sheep, several polymorphisms in the $P R N P$ open reading frame (ORF) are associated with the susceptibility to Creutzfeldt-Jakob disease (CJD) and scrapie, respectively. (Collinge et al., 1991; Palmer et al., 1991; Goldmann et al., 1994; Belt et al., 1995; Clouscard et al., 1995; Shibuya et al., 1998; Ironside et al., 2000). In contrast to the situation in humans and sheep, polymorphisms of an octapeptide repeat deletion and of codon 192 in cattle are not associated with the incidence 
of BSE (Hunter et al., 1994; Neibergs et al., 1994), while single-strand conformation polymorphisms (SSCPs) in the PRNP ORF and a 23-bp insertion/deletion polymorphism in the putative PRNP promoter region do show such an association (Neibergs et al., 1994; Sander et al., 2004). The $P R N P$ gene in cattle is less polymorphic than those in sheep and humans. Until now four polymorphisms, at codons $78,113,192$, and the deletion of an octapeptide repeat, have been identified in the coding region of bovine PRNP (Goldmann et al., 1991; Humeny et al., 2002). Although the polymorphisms of PRNP have been studied in many cattle breeds, including Holstein cattle, the polymorphisms of PRNP in Hanwoo animals have not previously been studied. The purpose of this study was to investigate genotype frequencies of $P R N P$ polymorphisms in 120 Hanwoo and 53 Holstein animals.

Blood samples were taken from 120 Hanwoo and 53 Holstein cattle between April 2000 and June 2003. After collection, all blood samples were frozen at $-70^{\circ} \mathrm{C}$ prior to analysis. Genomic DNA was extracted from $200 \mu \mathrm{l}$ of blood using a QIAamp DNA blood mini kit (Qiagen, USA) following the suppliers instructions. Polymerase chain reaction (PCR) was performed with Bp-1 (5'-CACATAGGCAGTTGGATCCTGG-3') and Bp-2 (5'-GGTACTGGGTAATGCACATTTGCTC-3') primers. These primers were designed to amplify a 676 -bp product including the bovine $P R N P$ ORF. The PCR reaction mixture contained 50 pmole of each primer, $5 \mu \mathrm{l}$ of $10 \times$ Taq DNA polymerase buffer, $1.5 \mathrm{mM} \mathrm{MgCl}, 0.2 \mathrm{mM}$ dNTPs, and 2.5 units of Taq DNA polymerase (Promega, USA). The PCR condition was as follows: an initial denaturation step of $95^{\circ} \mathrm{C}$ for $3 \mathrm{~min}, 35$ cycles of $95^{\circ} \mathrm{C}$ for $1 \mathrm{~min}, 54^{\circ} \mathrm{C}$ for $1 \mathrm{~min}$, and $72^{\circ} \mathrm{C}$ for 2 min and then a final extension at $72^{\circ} \mathrm{C}$ for 10 min. Restriction cleavage sites were searched using Webcutter, ver. 2.0 (Carolina Biological Supply Co., USA). PCR mixtures were purified with Gel Extraction Kits (Qiagen, USA). A $20 \mu \mathrm{l}$ aliquot of purified PCR mixture was digested at $37^{\circ} \mathrm{C}$ for $1 \mathrm{hr}$ with 5 units of Hind II (MBI, USA). The restriction products were separated on a 1.5\% agarose gel and visualized with ethidium bromide staining under UV light. The purification of PCR products for sequencing was done using a QIAquick gel extraction kit (Qiagen, USA). The DNA sequencing was carried out on an ABI 377 automatic sequencer using a Taq dideoxy terminator cycle sequencing kit (ABI, USA). The following sequencing primers were used: $\mathrm{Bp}-1, \mathrm{Bp}-2, \mathrm{Bp}-$ 3 (5'-GCCTCTGCAAGAAGCGACCAA-3'), Bp-4 (5'-ATCAAGATGTCAGTTTCGGTG-3'). Nucleic acid sequences were assembled and edited using the ABI 377 DNA Sequencer Data Analysis Program and Sequence Navigator Software. Statistical analyses were performed using SAS 8.1 Software (SAS Institute Inc., USA). $\chi^{2}$ tests were performed to analyze differences in genotype frequencies between Hanwoo and Holstein cattle raised in
Korea.

The first polymorphism was observed at the third position of codon $78(\mathrm{G} \rightarrow \mathrm{A})$ (Fig. 1A). There were no significant differences in the frequencies of genotype $\left(\chi^{2}=\right.$ 3.1926, $P=0.2026)$ or allele $\left(\chi^{2}=3.2412, P=0.7180\right)$ at codon 78 between Hanwoo and Holstein cattle (Table 1).

The second polymorphism was found at the third position of codon $192(\mathrm{C} \rightarrow \mathrm{T})$, and does not alter the encoded amino acid. In a previous study (Hunter et al., 1994), it was demonstrated that this polymorphism was not associated with BSE incidence. Electropherograms obtained by automatic DNA sequencing showed the polymorphism at codon 192 (Fig. 1B), which was also confirmed by using restriction endonuclease Hind II (Fig. 1C). There were significant differences in the frequencies of genotype $\left(\chi^{2}=\right.$ 20.1404, $P<0.0001)$ and allele $\left(\chi^{2}=20.2408, P<0.0001\right)$ at codon 192 between Hanwoo and Holstein cattle (Table $1)$.

The last polymorphism found in Korean cattle was the deletion of a single octa-repeat ( $24 \mathrm{bp})$. The deletion was found in 9 (8.5\% deleted allele frequency) of 53 Korean Holstein cattle. These are the first electropherograms showing a deletion of a single octa-repeat in cattle using an automatic DNA sequencer (Fig. 1D). The deletion found in 9 Holstein cattle was the R3 deletion (Fig. 1E). However, this deletion was not found in 120 Hanwoo animals. There were no homozygotic deletions of any octa-repeat in either Hanwoo or Holstein cattle (Table 1). The genotype $\left(\chi^{2}=21.4956, P<0.0001\right)$ and allele $\left(\chi^{2}=20.9216, P<0.0001\right)$ frequencies of a single octa-repeat-deletion were significantly different between Hanwoo and Holstein cattle raised in Korea (Table 1).

The polymorphism at codon 113 does not result in amino acid substitutions (Humeny et al. 2002). We also looked for the presence of polymorphism of $P R N P$ at the third position of codon $113(\mathrm{C} \rightarrow \mathrm{T})$. None of 120 Hanwoo or 53 Holstein cattle exhibited this polymorphism. Polymorphisms at codons other than 78 and 192 were not observed in the PRNP ORF of 120 Hanwoo and 53 Holstein cattle.

Based on these three polymorphisms, eight different genotypes for the PRNP were detected in Hanwoo and Holstein cattle (Table 2). In Holsteins raised in Korea, the most frequent PRNP genotype was ${ }^{\mathrm{CAG}} 78^{\mathrm{CAG}}$ / ${ }_{\mathrm{AAC}} 192^{\mathrm{AAC} /{ }^{+}} \mathrm{Octa}^{+}(37.7 \%)$, followed by ${ }^{\mathrm{CAG}} 78^{\mathrm{CAA}} / \mathrm{AAC}^{\mathrm{AAC}} 192^{\mathrm{AAC}} /$ ${ }^{+} \mathrm{Octa}^{+}(32.1 \%)$ and ${ }^{\mathrm{CAG}} 78^{\mathrm{CAG} / \mathrm{AAC}} 192^{\mathrm{AAC}} /{ }^{+} \mathrm{Octa}^{-}(9.4 \%)$. In Hanwoo, the most frequent $P R N P$ genotype was ${ }^{\mathrm{CAG}} 78^{\mathrm{CAA}}$ / ${ }_{\mathrm{AAC}} 192^{\mathrm{AAC}} /{ }^{+} \mathrm{Octa}^{+}(26.6 \%)$, followed by ${ }^{\mathrm{CAG}} 78^{\mathrm{CAA}} / \mathrm{AAC}^{\mathrm{AaC}} 192^{\mathrm{AAT}} /$ ${ }^{+} \operatorname{Octa}^{+}(17.5 \%)$ and ${ }^{\mathrm{CAG}} 78^{\mathrm{CAG}} / \mathrm{AAC}^{192} 2^{\mathrm{AAC}} /{ }^{+} \mathrm{Octa}^{+}(17.5 \%)$. A significant difference was found between the Hanwoo and Holstein groups in PRNP genotype distribution $\left(\chi^{2}=\right.$ 44.2370, $P<0.0001$ ).

The ORF of $P R N P$ is more polymorphic in humans and sheep than in cattle. In human $P R N P$, polymorphisms have been found in the region of octapeptide repeats and 
A
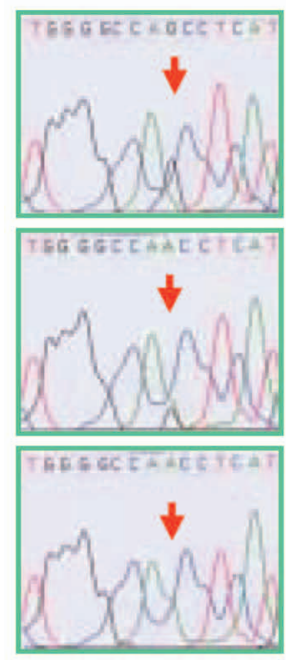

B
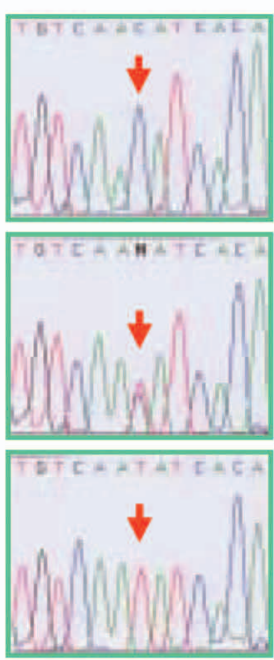

C

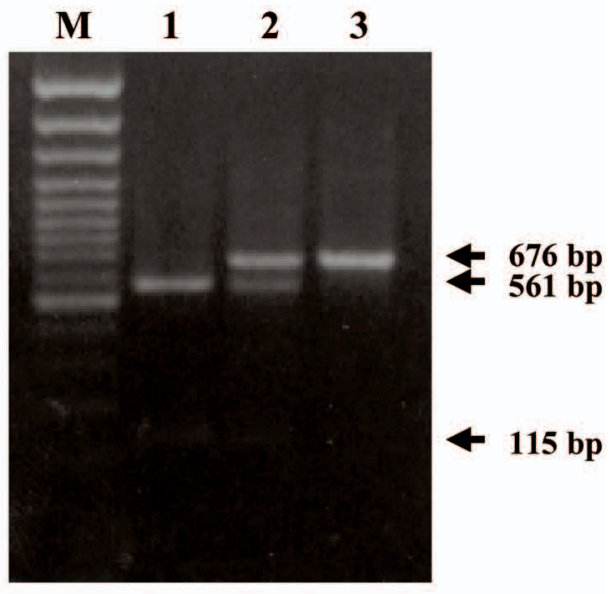

D
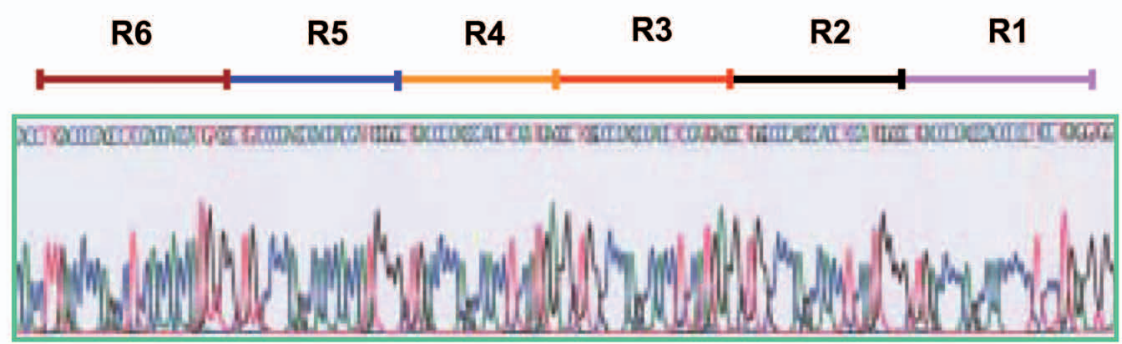

No Deletion/

No deletion

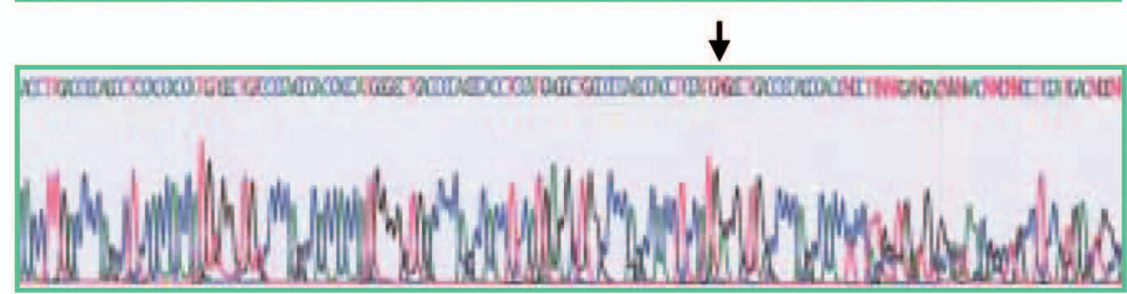

\section{No Deletion/}

$\mathrm{R} 3$ deletion

\section{$\mathbf{E}$}

\begin{tabular}{llllllllll|} 
R1 & CCT & CAG & GGA & GGG & GGT & GGC & TGG & GGT & CAG \\
R2 & CCC & CAT & GGA & $\ldots$ & GGT & GGC & TGG & GGC & CAG \\
\hline R3 & CCT & CAT & GGA & $\ldots$ & GGT & GGC & TGG & GGC & CAG \\
\hline R4 & CCT & CAT & GGA & $-\cdots$ & GGT & GGC & TGG & GGT & CAG \\
R5 & CCC & CAT & GGT & $\ldots$ & GGT & GGC & TGG & GGA & CAG \\
R6 & CCA & CAT & GGT & GGT & GGA & GGC & TGG & GGT & CAA
\end{tabular}

Fig. 1. Polymorphisms at codons 78, 192, and octa-repeat region in samples of Korean Holstein and Hanwoo cattle. (A) Electropherograms showing the three genotypes at polymorphic codon 78 of Holstein and Hanwoo cattle. Upper portion: CAG/CAG, middle portion: CAG/CAA, lower portion: CAA/CAA. (B) Electropherograms showing the three genotypes at polymorphic codon 192 of Hanwoo. Upper portion: AAC/AAC, middle portion: AAC/AAT, lower portion: AAT/AAT. (C) Restriction analysis of PrP ORF digested with Hind II, which cleaves codon 192 when it is AAC. M: 100-bp ladder DNA marker, lane 1: AAC/AAC, lane 2: AAC/AAT, lane 3: AAT/AAT. (D) Electropherograms showing the polymorphism at the octapeptide repeat region. The deletion of a single octapeptide repeat (24 bp) was found in Korean Holstein cattle. Upper portion: no deletion/no deletion, Lower portion: an octapeptide repeat deletion/no deletion. (E) The deletion R3 of the repeat region of PRNP. The dark box represents the deletion found in all cases with R3 deletion. The abbreviated name for each repeat is shown on the left. 
Table 1. Genotype and allele frequencies of the $P R N P$ polymorphism at codons 78,192 , and octapeptide repeat region in Korean Holstein and Hanwoo cattle

\begin{tabular}{|c|c|c|c|c|c|c|c|}
\hline \multirow{2}{*}{ Polymorphism } & \multirow{2}{*}{ Sample } & \multirow{2}{*}{$\begin{array}{c}\text { Total, } \\
\mathrm{n}\end{array}$} & \multicolumn{3}{|c|}{ Genotype frequency, n (\%) } & \multicolumn{2}{|c|}{ Allele frequency } \\
\hline & & & G/G & G/A & $\mathrm{A} / \mathrm{A}$ & $G$ & $\mathrm{~A}$ \\
\hline \multirow{3}{*}{ Codon 78} & Holstein & 53 & $27(51.0)$ & $22(41.5)$ & $4(7.5)$ & 0.717 & 0.283 \\
\hline & Hanwoo & 120 & $47(39.2)$ & $54(45.0)$ & $19(15.8)$ & 0.617 & 0.383 \\
\hline & & & \multicolumn{3}{|c|}{$\begin{array}{l}\left(\chi^{2}=3.1926\right. \\
P=0.2026)\end{array}$} & \multicolumn{2}{|c|}{$\begin{array}{l}\left(\chi^{2}=3.2412\right. \\
P=0.7180)\end{array}$} \\
\hline \multirow{2}{*}{ Polymorphism } & \multirow{2}{*}{ Sample } & \multirow{2}{*}{$\begin{array}{c}\text { Total, } \\
\mathrm{n}\end{array}$} & \multicolumn{3}{|c|}{ Genotype frequency, n (\%) } & \multicolumn{2}{|c|}{ Allele frequency } \\
\hline & & & $\mathrm{C} / \mathrm{C}$ & $\mathrm{C} / \mathrm{T}$ & $\mathrm{T} / \mathrm{T}$ & $\mathrm{C}$ & $\mathrm{T}$ \\
\hline \multirow{3}{*}{ Codon 192} & Holstein & 53 & $49(92.5)$ & $4(7.5)$ & $0(0)$ & 0.962 & 0.038 \\
\hline & Hanwoo & 120 & $70(58.3)$ & $43(35.8)$ & $7(5.8)$ & 0.763 & 0.237 \\
\hline & & & \multicolumn{3}{|c|}{$\begin{aligned}\left(\chi^{2}\right. & =20.1404 \\
P & <0.0001)\end{aligned}$} & \multicolumn{2}{|c|}{$\begin{aligned}\left(\chi^{2}\right. & =20.2048 \\
P & <0.0001)\end{aligned}$} \\
\hline \multirow{2}{*}{ Polymorphism } & \multirow{2}{*}{ Sample } & \multirow{2}{*}{$\begin{array}{c}\text { Total, } \\
\mathrm{n}\end{array}$} & \multicolumn{3}{|c|}{ Genotype frequency, n (\%) } & \multicolumn{2}{|c|}{ Allele frequency } \\
\hline & & & $6 / 6$ & $6 / 5^{\mathrm{a}}$ & $5 / 5$ & 6 & 5 \\
\hline \multirow{3}{*}{$\begin{array}{l}\text { Octapeptide } \\
\text { repeat region }\end{array}$} & Holstein & 53 & $44(83.0)$ & $9(17.0)$ & $0(0)$ & 0.915 & 0.085 \\
\hline & Hanwoo & 120 & $120(100)$ & $0(0)$ & $0(0)$ & 1 & 0 \\
\hline & & & \multicolumn{3}{|c|}{$\begin{aligned}\left(\chi^{2}\right. & =21.4956 \\
P & <0.0001)\end{aligned}$} & \multicolumn{2}{|c|}{$\begin{aligned}\left(\chi^{2}\right. & =20.9216 \\
P & <0.0001)\end{aligned}$} \\
\hline
\end{tabular}

${ }^{\mathrm{a}} 6$ indicates no deletion of octa-repeat $(24 \mathrm{bp})$ and 5 indicates a deletion of one octa-repeat.

Table 2. Genotype distribution for codons 78, 192 and octarepeat region of PRNP in Korean Holstein and Hanwoo cattle

\begin{tabular}{|c|c|c|}
\hline Genotype & $\begin{array}{l}\text { Holstein, } \\
\mathrm{n}=53(\%)\end{array}$ & $\begin{array}{c}\text { Hanwoo, } \\
\mathrm{n}=120(\%)\end{array}$ \\
\hline${ }_{\mathrm{CAG}} 78^{\mathrm{CAA}} / A^{\mathrm{AAC}} 192^{\mathrm{AAC}} /{ }^{+} \mathrm{Octa}^{+\mathrm{a}}$ & $17(32.1)$ & $32(26.6)$ \\
\hline${ }^{\mathrm{CAG}} 78^{\mathrm{CAA} /{ }^{\mathrm{AAC}}} 192^{\mathrm{AAT}} /{ }^{+} \mathrm{Octa}^{+}$ & $2(3.8)$ & $21(17.5)$ \\
\hline${ }^{\mathrm{CAG}} 78^{\mathrm{CAG}} /{ }^{\mathrm{AAC}} 192^{\mathrm{AAC}} /{ }^{+} \mathrm{Octa}^{+}$ & $20(37.7)$ & $21(17.5)$ \\
\hline${ }^{\mathrm{CAG}} 78^{\mathrm{CAG} /{ }^{\mathrm{AAC}}} 192^{\mathrm{AAT}} /{ }^{+} \mathrm{Octa}^{+}$ & $1(1.9)$ & $20(16.7)$ \\
\hline${ }^{\mathrm{CAA}} 78^{\mathrm{CAA} / \mathrm{AAC}^{\mathrm{A}}} 192^{\mathrm{AAC}} /{ }^{+} \mathrm{Octa}^{+}$ & $4(7.5)$ & $17(14.2)$ \\
\hline${ }^{\mathrm{CAG}} 78^{\mathrm{CAG}} / \mathrm{AAT}^{-19} 2^{\mathrm{AAT}} /{ }^{+} \mathrm{Octa}^{+}$ & $0(0)$ & $6(5)$ \\
\hline${ }^{\mathrm{CAA}} 78^{\mathrm{CAA}} /{ }^{\mathrm{AAC}} 192^{\mathrm{AAT}} /{ }^{+} \mathrm{Octa}^{+}$ & $0(0)$ & $2(1.7)$ \\
\hline${ }^{\mathrm{CAG}} 78^{\mathrm{CAA} / \mathrm{AAT}^{\mathrm{A}}} 192^{\mathrm{AAT}} /{ }^{+} \mathrm{Octa}^{+}$ & $0(0)$ & $1(0.8)$ \\
\hline${ }^{\mathrm{CAG}} 78^{\mathrm{CAG}} /{ }^{\mathrm{AAC}} 192^{\mathrm{AAC}} /{ }^{+} \mathrm{Octa}^{-}$ & $5(9.4)$ & $0(0)$ \\
\hline${ }^{\mathrm{CAG}} 78^{\mathrm{CAA} / \mathrm{AAC}^{\mathrm{AAC}}} 192^{\mathrm{AAC}} /{ }^{+} \mathrm{Octa}^{-}$ & $3(5.7)$ & $0(0)$ \\
\hline${ }^{\mathrm{CAG}} 78^{\mathrm{CAG} /{ }^{\mathrm{AAC}}} 192^{\mathrm{AAT}} /{ }^{+} \mathrm{Octa}^{-}$ & $1(1.9)$ & $0(0)$ \\
\hline
\end{tabular}

${ }^{\mathrm{a}+}$ Octa indicates no deletion of octa-repeat $(24 \mathrm{bp})$ and ${ }^{-}$Octa indicactes a deletion of octa-repeat.

at codons 102,117, 124, 129, 161, 171, and 219 (Laplanche et al., 1990; Fink et al., 1994; Petraroli and Pocchiari 1996; Jeong et al., 2004). In sheep, amino acid polymorphisms have been described previously at codons $112,136,137,138,141,151,154,171$, and 211 (Laplanche et al., 1993; Westaway et al., 1994; Belt et al., 1995; Bossers et al., 1996; Hunter et al., 1996; Thorgeirsdotteir et al., 1999; Tranulis et al., 1999). On the other hand, only three polymorphisms were found in the coding region of the Korean bovine PRNP: in the region of octapeptide repeats and at codons 78 and 192 . We found that the genotype frequencies of $P R N P$ polymorphism at codon 78 in 53 Korean Holsteins were 51.0\% CAG/CAG, 41.5\% CAG/CAA, and 7.5\% CAA/CAA, while in 120 Hanwoo they were $39.2 \% \mathrm{CAG} / \mathrm{CAG}, 45.5 \% \mathrm{CAG} / \mathrm{CAA}$, and $15.8 \%$ CAA/CAA (Table 1). These values are similar to those observed for the Simmenthal and Gelbvieh (Humeny et al. 2002). The polymorphism at codon 78 has not been shown to influence the susceptibility to BSE. In a previous study (Neibergs et al., 1994), using SSCPs, genotypic differences were detected between BSE-affected cattle and unrelated British Friesian cattle $(P<0.001)$. In the future, analysis of the polymorphism at codon 78 in BSE cattle will help to evaluate any potential correlation between polymorphisms of bovine PRNP and susceptibility to BSE.

The genotype frequencies of PRNP polymorphism at codon 192 in Korean Holsteins were different from those in Hanwoo (Table 1). In a previous study (Hunter et al., 1994), comparison of this polymorphism in cattle with and without BSE did not reveal a significant difference.

The prion protein in cattle contains a region of 6 octarepeats, named $\mathrm{R} 1$ through $\mathrm{R} 6$. The $P R N P$ alleles containing five, six, or seven octa-repeats are named $P R N P 5$, $P R N P 6$, and $P R N P 7$, respectively. The PRNP octarepeat allele genotype variations were analyzed among cattle in the USA, Poland, Croatia, Belgium, Scotland and Switzerland (McKenzie et al., 1992; Brown et al., 1993; Hunter et al., 1994; Schlapfer et al., 1999; Premzl et al., 2000; Walawski and Czarnik 2003). No major differences were detected among various cattle breeds in these 
countries, with the exception of the Swiss Brown breed in Switzerland (Schlapfer et al., 1999). The deletion found in most cattle is usually the R3 deletion. The octapeptide deletions in bovine PRNP are not associated with the incidence of BSE (Hunter et al., 1994). The allele frequencies of the octa-repeat polymorphism differ slightly in various cattle breeds (Hunter et al., 1994; Schlapfer et al., 1999; Premzl et al., 2000; Humeny et al., 2002; Walawski and Czarnik 2003). We did not detect the PRNP7 allele that has been detected only in the Swiss Brown breed in Switzerland (Schlapfer et al., 1999). An analysis of 53 Korean Holsteins revealed genotype frequencies of $91.5 \%$ PRNP6 allele and $8.5 \%$ PRNP5 allele. However, 120 Hanwoo had a $100 \%$ frequency of PRNP6 allele (Table 1). The allele frequency of octarepeat polymorphism showed a significant difference between Korean Holsteins and Hanwoo $(P<0.0001)$.

In a previous study (Humey et al., 2002), another polymorphism was reported at codon 113 (CCC/CCT). This polymorphism was not found in Korean Hanwoo or Holstein cattle.

In conclusion, as noted previously, data on a number of bovine PRNP polymorphisms in many countries have been reported. However, among Asian countries, the genotype distribution of bovine PRNP polymorphisms has been reported only in Japan (Takasuga et al., 2003). Our data will be useful for comparison with genotype frequency studies done in other Asian countries as those data become available.

We thank Dr. Yong Hee Kim for assistance with the statistical analysis. This study was supported by the High-Technology Development Project in Technology Development Program for Agriculture and Forestry, Ministry of Agriculture and Forestry, Republic of Korea (Project No. 204111-03).

\section{REFERENCES}

Belt, P. B., Muileman, I. H., Schreuder, B. E., Bos-de Ruijter, J., Gielkens, A. L., and Smits, M. A. (1995) Identification of five allelic variants of the sheep $\operatorname{PrP}$ gene and their association with natural scrapie. J. Gen. Virol. 76, 509-517.

Bossers, A., Schreuder, B. E., Muileman, I. H., Belt, P. B., and Smits, M. A. (1996) PrP genotype contributes to determining survival times of sheep with natural scrapie. J. Gen. Virol. 77, 2669-2673.

Brown, D. R., Zhang, H. M., DeNise, S. K., and Ax, R. L. (1993) Bovine prion gene allele frequencies determined by AMFLP and RFLP analysis. Anim. Biotechnol. 4, 47-51.

Clouscard, C., Beaudry, P., Elsen, J. M., Milan, D., Dussaucy, M., Bounneau, C., Schelcher, F., Chatelain, J., Launay, J. M., and Laplanche, J. L. (1995) Different allelic effects of the codons 136 and 171 of the prion protein gene in sheep with natural scrapie. J. Gen. Virol. 76, 2097-2101.

Fink, J. K., Peacock, M. L., Warren, J. T. Jr., Roses, A. D., and Prusiner, S. B. (1994) Detecting prion protein gene mutations by denaturing gradient gel electrophoresis. Hum. Mutat. 4, 42-50.
Goldmann, W., Hunter, N., Martin, T., Dawson, M., and Hope, J. (1991) Different forms of the bovine PrP gene have five or six copies of a short, G-C-rich element within the protein coding exon. J. Gen. Virol. 72, 201-204.

Goldmann, W., Hunter, N., Smith, G., Foster, J., and Hope, J. (1994) PrP genotype and agent effects in scrapie: change in allelic interaction with different isolates of agent in sheep, a natural host of scrapie. J. Gen. Virol. 75, 989-995.

Hope, J., Reekie, L. J., Hunter, N., Multhaup, G., Beyreuther, K., White, H., Scott, A. C., Stack, M. J., Dawson, M., and Wells, G. A. (1988) Fibrils from brains of cows with new cattle disease contain scrapie-associated protein. Nature $\mathbf{3 3 6}$, 390-392.

Horiuchi, M., Ishiguro, N., Nagasawa, H., Toyoda, Y., and Shinagawa, M. (1998) Genomic structure of the bovine PrP gene and complete nucleotide sequence of bovine PrP cDNA. Anim. Genet. 29, 37-40.

Humeny, A., Schiebel, K., Seebeer, S., and Becker, C. M. (2002) Identification of polymorphisms within the bovine prion protein gene (PrnP) by DNA sequencing and genotyping by MALDI-TOF-MS. Neurogenet. 4, 59-60.

Hunter, N., Foster, J. D., Goldmann, W., Stear, M. J., Hope, J., and Bostock, C. (1996) Natural scrapie in a closed flock of Cheviot sheep occurs only in specific PrP genotypes. Arch. Virol. 141, 809-824.

Hunter, N., Goldmann, W., Smith, G., and Hope, J. (1994) Frequencies of $\operatorname{PrP}$ gene variants in healthy cattle and cattle with BSE in Scotland. Vet. Rec. 135, 400-403.

Jeong, B. H., Nam, J. H., Lee, Y. J., Lee, K. H., Jang, M. K, Carp, R. I., Lee, H. D., Ju, Y. R., Jo, S. A., Park K. Y., and Kim, Y. S. (2004) Polymorphisms of the prion protein gene (PRNP) in a Korean population. J. Hum. Genet. 49, 319324.

Kimura, K. M., Haritani, M., Kubo, M., Hayasaka, S., and Ikeda, A. (2002) Histopathological and immunohistochemical evaluation of the first case of BSE in Japan. Vet. Rec. 151, 328-330.

Kirkwood, J. K., and Cunningham, A. A. (1994) Epidemiological observations on spongiform encephalopathies in captive wild animals in the British Isles. Vet. Rec. 135, 296-303.

Koo, H. C., Park, Y. H., Lee, B. C., Chae, C. H., O'rourke, K. I., and Baszler, T. V. (2001) Immunohistochemical detection of prion protein (PrP-Sc) and epidemiological study of BSE in Korea. J. Vet. Sci. 2, 25-31.

Laplanche, J. L., Chatelain, J., Launay, J. M., Gazengel, C., and Vidaud, M. (1990) Deletion in prion protein gene in a Moroccan family. Nucleic Acids Res. 18, 6745.

McKenzie, D. I., Cowan, C. M., Marsh, R. F., and Aiken, J. M. (1992) $\operatorname{PrP}$ gene variability in the USA cattle population. Anim. Biotechnol. 3, 309-315.

Neibergs, H. L., Ryan, A. M., Womack, J. E., Spooner, R. L., and Williams, J. L. (1994) Polymorphism analysis of the prion gene in BSE-affected and unaffected cattle. Anim. Genet. 25, 313-317.

Palmer, M. S., Dryden, A. J., Hughes, J. T., and Collinge, J. (1991) Homozygous prion protein genotype predisposes to sporadic Creutzfeldt-Jakob disease. Nature, 352, 340-342.

Petraroli, R., and Pocchiari, M. (1996) Codon 219 polymorphism of PRNP in healthy Caucasians and Creutzfeldt-Jakob disease patients. Am. J. Hum. Genet. 58, 888-889.

Premzl, M., Bozic, P., and Gamulin, V. (2000) PRNP octa-repeat allele genotype frequencies among the modern and rare cattle breeds in Croatia. Anim. Genet. 31, 408-409.

Ryan, A. M., and Womack, J. E. (1993) Somatic cell mapping of the bovine prion protein gene and restriction fragment 
length polymorphism studies in cattle and sheep. Anim. Genet. 24, 23-26.

Sander P, Hamann H, Pfeiffer I, Wemheuer W, Bertram B, Groshup MH, Ziegler U, Distl O, and Leeb T. (2004) Analysis of sequence variability of the bovine prion protein gene (PRNP) in German cattle breeds. Neurogenet. 5, 19-25.

Schlapfer, I., Saitbekova, N., Gaillard, C., and Dolf, G. (1999) A new allelic variant in the bovine prion protein gene (PRNP) coding region. Anim. Genet. 30, 386-387.

Shibuya, S., Higuchi, J., Shin, R. W., Tateishi, J., and Kitamoto, T. (1998) Codon 219 Lys allele of PRNP is not found in sporadic Creutzfeldt-Jakob disease. Ann. Neurol. 43, 826828.

Takasuga, A., Abe, T., Ito T., Watanabe, T., Kamatani, N., and Sugimoto, Y. (2003) Novel prion protein polymorphisms in cattle. Anim. Genet. 34, 396-397.

Thorgeirsdotteir, S., Sigurdarson, S., Thorisson, H. M., Georgsson, G., and Palsdottir, A. (1999) PrP gene polymorphism and natural scrapie in Icelandic sheep. J. Gen. Virol. 80, $2527-2534$.
Tranulis, M. A., Osland, A., Bratberg, B., and Ulvund, M. J. (1999) Prion protein gene polymorphism in sheep with natural scrapie and healthy controls in Norway. J. Gen. Virol. 80, 1073-1077.

Walawski, K., and Czarnik, U. (2003) Prion octapeptide-repeat polymorphism in Polish Black-and-White cattle. J. Appl. Genet. 44, 191-195.

Wells, G. A. H., Scott, A. C., Johnson, C. T., Gunning, R. F., Hancock, R. D., Jeffrey, M., Dawson, M., and Bradley, R. (1987) A novel progressive spongiform encephalopathy in cattle. Vet. Rec. 121, 419-420.

Westaway, D., Zuliani, V., Mirenda Cooper, C., Da Costa, M., Neuman, S., Jenny, A. L., Detwiler, L., and Prusiner, S. B. (1994) Homozygosity for prion protein alleles encoding glutamine 171 renders sheep susceptible to natural scrapie. Genes Dev. 8, 959-969.

Yoshimoto, J., Iinuma, T., Ishiguro, N., Horiuchi, M., Imamura, M., and Shinagawa, M. (1992) Comparative sequence analysis and expression of bovine PrP gene in mouse L-929 cells. Virus Genes 6, 343-356. 